\author{
Anna Piszcz \\ University of Bialystok \\ piszcz@uwb.edu.pl
}

\title{
Well Begun is Half Done: Amendments to the Polish Legal Framework for Consensual Dispute Resolution Needed After Antitrust Damages Directive (2014/104/EU)
}

\begin{abstract}
This article concentrates on amendments to the Polish legal framework for consensual dispute resolution that are needed after Antitrust Damages Directive (2014/104/EU). It starts with the general context of changes in consensual dispute resolution resulting from the Directive. In this regard, it provides an overview of approaches to consensual dispute resolution in the Commissions' Green and White papers as well as in the preamble to the Damages Directive. Also, it shows how consensual dispute resolution is defined in the Directive. The remainder of the article is structured as follows. It continues with the presentation of legal solutions regarding the effects of consensual dispute resolution. In short, it explains these effects on limitation periods, proceedings and fines. Furthermore, the article presents the effect of consensual settlements on subsequent actions for damages as well. Both legal solutions contained in the Damages Directive and Polish draft legal provisions implementing the Directive are discussed in this article. It concludes with a short summary.
\end{abstract}

Keywords: antitrust, Damages Directive, consensual dispute resolution

\section{Introduction}

This article relates to consensual dispute resolution mechanisms (out-of-court settlements, arbitration, mediation or conciliation) serving private enforcement of competition law. On 11 June 2013 the European Commission (hereinafter, also the Commission) adopted a package of measures to address the lack of efficient private enforcement of European Union (EU) competition law. In particular, a proposal for a Directive on actions for damages ${ }^{1}$ (hereinafter: Directive or Damages Directive)

1 Proposal for a Directive of the European Parliament and of the Council on certain rules governing actions for damages under national law for infringements of the competition law provisions of the Member States and of the European Union, COM (2013) 404 final (11.06.2013). 
accompanied by the Impact Assessment and its Executive Summary, a non-binding Communication ${ }^{2}$ and a Practical Guide to the quantification of harm in antitrust infringements, ${ }^{3}$ as well as a horizontal Recommendation on collective redress ${ }^{4}$ were adopted to meet the need for a coherent European approach to private enforcement of EU competition law. On 26 November 2014, the Damages Directive was finally adopted. ${ }^{5}$ The Directive refers to consensual dispute resolution in Recitals 5 and 48-52, Chapter1 Article 2(21)-(22) and Chapter VI Articles 18-19.

By 27 December 2016, EU Member States were supposed to have implemented the Directive into their legal systems. Poland has failed to do this in a timely manner. This article presents legal solutions resulting from the Directive. My argument is that the Polish legal framework needs amendments if Poland is to do what she is obliged to do, i.e. implement the Directive without further delay. My observations will be explained and discussed on the background of: (1) the draft Act on Claims for Damages for Infringements of the Competition Law Provisions (hereinafter, the draft Act), (2) the Explanatory Notes accompanying the draft Act (hereinafter Explanatory Notes), both having been changed by the Ministry of Justice as a responsible unit on 22 December 2016 after public consultations and forwarded to the European Affairs Committee at the Ministry of Foreign Affairs. ${ }^{6}$ Specific questions for discussion are the effect of consensual dispute resolution on limitation periods, proceedings and fines, and the effect of consensual settlements on subsequent actions for damages. Although drafters are in the process of completing implementation works, the article offers recommendations in this regard. The point of the analysis is both normative and descriptive.

\section{Consensual dispute resolution in the legal framework for private enforcement of EU competition law}

First this section will summarize some key points in the development of private enforcement of EU competition law. Over the course of one decade, the Commission

2 Communication from the Commission on quantifying harm in actions for damages based on breaches of Article 101 or 102 of the Treaty on the Functioning of the European Union (2013/C 167/07), OJ C 167/19 (13.06.2013).

3 Commission Staff Working Document - Practical guide Quantifying harm in actions for damages based on breaches of Article 101 or 102 of the Treaty on the functioning of the European Union, C (2013) 3440 (11.06.2013).

4 Commission Recommendation of 11 June 2013 on common principles for injunctive and compensatory collective redress mechanisms in the Member States concerning violations of rights granted under Union Law (2013/396/EU), OJ L 201/60 (26.07.2013).

5 Directive 2014/104/EU of the European Parliament and of the Council of 26 November 2014 on certain rules governing actions for damages under national law for infringements of the competition law provisions of the Member States and of the European Union, OJ L 349/1 (05.12.2014). The drafts are available in Polish at: https://legislacja.rcl.gov.pl/projekt/12292051/kata$\log / 12389807 \# 12389807$ (30.12.2016). 
Well Begun is Half Done: Amendments to the Polish Legal Framework...

published the 2005 Green Paper - Damages actions for breach of the EC antitrust rules, ${ }^{7}$ the 2008 White Paper on Damages Actions for Breach of the EC Antitrust Rules ${ }^{8}$ and the 2013 package mentioned above in the introduction. ${ }^{9}$

With the Green Paper, the Commission established a basis for meaningful analysis and discussion of private enforcement of EU competition law. However, the Green Paper did not even contain a mention of consensual dispute resolution.

After a short hiatus, in 2008 the White Paper was published by the Commission. The White Paper, by comparison, stated that "Due consideration should be given to mechanisms fostering early resolution of cases, e.g., by settlements" (para. 2.8). At the same time, the White Paper stressed that "This could significantly reduce or eliminate litigation costs for the parties and also the costs for the judicial system". For the reasons stipulated in Chapter 9 of the Commission staff working paper on EC antitrust damages actions accompanying the White Paper, the Commission encouraged Member States to design procedural rules fostering settlements as a means to reduce costs. Therefore, at least in relation to consensual dispute resolution, the White Paper seemed to be concerned above all else about the effective reduction of costs of actions for damages. However, it does prove that the role of consensual dispute resolution in private enforcement of competition law had been noticed long before the proposal for the Damages Directive.

The construction of detailed solutions relating to consensual dispute resolution in the Damages Directive was vital. The role of the consensual dispute resolution mechanism has become more important than ever before in resolving disputes. It has been acclaimed as the way to save money and manpower in undertakings, shorten the time of dispute resolution and sustain a healthier business environment. According to Recital 5 of the Directive: "Actions for damages are only one element of an effective system of private enforcement of infringements of competition law and are complemented by alternative avenues of redress, such as consensual dispute resolution and public enforcement decisions that give parties an incentive to provide compensation" ${ }^{10}$ Article 2(21) of the Directive contains the definition of consensual dispute resolution in the light of which it is any mechanism enabling parties to reach an out-of-court resolution of a dispute concerning a claim for damages.

$7 \quad \operatorname{COM}(2005) 672$.

8 COM (2008) 165.

9 The Commission's documents were preceded by the jurisprudence of the Court of Justice. In particular it is worth taking note of the Court's first, and so far, major decision on the right to antitrust damages open to any individual in Courage/Crehan. See judgment in case C-453/99 (ECLI:EU:C:2001:465). However, it did not address the issue of consensual dispute resolution.

10 To find out more about Recital 5, see A. Piszcz, Piecemeal Harmonisation Through the Damages Directive? Remarks on What Received Too Little Attention in Relation to Private Enforcement of EU Competition Law, "Yearbook of Antitrust and Regulatory Studies" 2015, vol. 8(12), p. 85. 
After Recital 5 the analysis moves on to Recital 48. It states that infringers and injured parties (as many of them as legally possible) should be encouraged to agree on compensating for the harm caused by a competition law infringement through consensual dispute resolution mechanisms. Achieving a 'once-and-for-all' settlement for defendants is considered by the Directive to be desirable in order to reduce uncertainty for infringers and injured parties. A selection of consensual dispute resolution mechanisms is presented in Recital 48 sentence 2 to cover out-of-court settlements (including those where a judge can declare a settlement binding), arbitration, mediation as well as conciliation. The provisions on consensual dispute resolution contained in the Directive are meant to reach two combined goals: facilitate the use of such mechanisms and increase the effectiveness thereof.

\section{Effects of consensual dispute resolution on limitation periods, proceedings and fines}

\subsection{Limitation periods}

Article 18 para. 1 of the Directive grants a suspensive effect to consensual dispute resolution in terms of the limitation period for bringing an action for damages. Member States are obliged to ensure that this limitation period is suspended for the duration of any consensual dispute resolution process. The suspension of the limitation period applies only with regard to those parties that are or that were involved or represented in the consensual dispute resolution. The aim of these provisions is to provide both sides with a genuine opportunity to engage in consensual dispute resolution before bringing proceedings before national courts (Recital 49 sentence 2 of the Preamble). Of academics, R. Moisejevas believes that Article 18 para. 1 in essence deals with situations where the parties attempt to resolve the case primarily through mediation or conciliation. ${ }^{11}$

In Poland, provisions related to this topic are contained in Article $123 \$ 1$ (1) and (3) of the Civil Code ${ }^{12}$. They state that the limitation period shall be interrupted ${ }^{13}$ by any activity before the court or other authority entitled to hear cases or enforce claims of a given kind or before the court of arbitration, undertaken directly either to pursue, declare, satisfy or to secure claims, as well as by the initiation of mediation. Additionally, Article 36 of the Act of 23 September 2016 on out-of-court consumer

11 R. Moisejevas, The Damages Directive and Consensual Approach to Antitrust Enforcement, "Yearbook of Antitrust and Regulatory Studies" 2015, vol. 8(12), pp. 187-188.

12 The Act of 23 April 1964 (consolidated text Journal of Laws 2016, item 380, as amended).

13 When the above-mentioned proceedings are concluded, the limitation period shall begin to run anew. 
Well Begun is Half Done: Amendments to the Polish Legal Framework...

disputes resolution ${ }^{14}$ states that the initiation of proceedings on the out-of-court consumer disputes resolution interrupts the limitation period of the claim at issue.

In the opinion of the Polish drafters, there is no need to amend these provisions. The drafters believe these provisions are to a large extent similar to those of the Directive; but they are not. They certainly refer to arbitration and mediation. But what of the other forms of consensual dispute resolution? According to Recital 48 sentence 2 of the Directive, conciliation and out-of-court settlements are also forms of consensual dispute resolution. As to the first, even though conciliation interrupts the limitation period pursuant to Article $123 \$ 1$ (1) of the Civil Code, normally it is a mechanism enabling parties to reach the resolution of a dispute in the form of a settlement concluded before a judge, not in the form of an out-of-court settlement. Under the Polish Civil Procedure Code, it is possible to apply to the court for convening to a conciliation hearing (Articles 184 et seq. of the Civil Procedure Code ${ }^{15}$ ). As to out-of-court settlements other than those concluded before the mediator or arbitrator, the process leading to their conclusion does not influence the limitation period. The Polish drafters believe this does not require any amendment to Article $123 \$ 1$ of the Civil Code, since in their view "consensual dispute resolution processes" in the meaning of Article 18 para. 1 of the Directive, include only those ways of out-of-court dispute resolution that are conducted within a certain framework, as procedures (otherwise, it would not be possible to establish the time of initiation and completion of the "process", which would result in legal uncertainty). ${ }^{16}$

From my point of view, this position is incorrect. Maybe this has to do with linguistic interpretation of the Polish version of Article 18 para. 1 of the Directive in which the English word "process" has been translated to Polish as procedura ("procedure"), whereas it is not necessarily used in this meaning in the Directive (for example in Recital 45 sentence 2 of the Directive, it states that "Quantifying harm in competition law cases is a very fact-intensive process"). Furthermore, the drafters have not taken into account the views of both foreign and national scholars in this regard. In the scholarly commentaries, it is emphasised that consensual dispute resolution should be understood broadly to cover also negotiations between the parties and/or their lawyers and is thus not limited to formal mechanisms of dispute resolution, ${ }^{17}$ even though, in order to rely on the suspensive effects referred to in Article 18

14 Journal of Laws 2016, item 1823.

15 The Act of 17 November 1964 (consolidated text Journal of Laws 2016, item 1822, as amended). See also A. Piszcz, Polish Civil Proceedings: Expanding the Floor for Preparatory Stage, (in:) L. Ervo, A. Nylund (eds.), Current Trends in Preparatory Proceedings, Cham 2016, p. 177.

16 In the Explanatory Notes, p. 25.

17 See F. Wijckmans, M. Visser, S. Jaques, E. Noël, The EU Private Damages Directive - Practical Insights. Minutes of the Closed Workshop 2015, Cambridge - Antwerp - Portland 2015, p. 76. See also M. Modzelewska de Raad, Polubowne rozstrzyganie sporów wynikających ze szkód wyrządzonych naruszeniem prawa konkurencji, (in:) A. Piszcz, D. Wolski (eds.), Dochodzenie przed 
para. 1 of the Directive, evidence should be provided that the negotiations had actually taken place.

Another issue is that Article 123 of the Civil Code provides for the interruption of limitation periods, which is more beneficial for injured parties, and not the suspension thereof (suspension is provided for in other situations). Should this be amended, even though it would undermine the "philosophy" of the Polish system of provisions on limitation periods? In my opinion, it is possible to solve this problem and implement Article 18 para. 1 of the Directive without necessarily going as far as such amendment. On one hand, the provision at issue refers literally to the suspension of limitation periods. On the other, it needs a systemic interpretation to a reasonable extent. Article 18 para. 1 is related to provisions on limitation periods contained in Article 10 of the Directive. They tend to treat the suspension and interruption of limitation periods as options depending on national laws. In Poland, traditionally the effect of activities undertaken directly to pursue, declare, satisfy or to secure claims has been the interruption of the limitation period. ${ }^{18}$

In summary, if Poland is to implement Article 18 para. 1 of the Directive with a minimum of modifications, only Article 123 of the Civil Code should be amended so that it includes also negotiations between the parties and/or their lawyers or a lex specialis vis-à-vis Article 123 should be introduced relating only to competition law cases.

\subsection{Proceedings}

Also noteworthy is a suspensive effect of consensual dispute resolution in terms of court proceedings. According to Article 18 para. 2 of the Directive, without prejudice to provisions of national law in matters of arbitration, Member States shall ensure that national courts seized of an action for damages may suspend their proceedings for up to two years where the parties thereto are involved in consensual dispute resolution concerning the claim covered by that action for damages. Recital 50 sentence 2 of the Directive adds that, when considering whether to suspend the proceedings, the national court bases its considerations on criteria in the form of the advantages of an expeditious procedure.

Article 178 of the Civil Procedure Code allows the court to suspend proceedings for up to one year upon the request of both parties irrespective of the reason. To be more correct, according to Article $182 \$ 1$ of the Code, the court shall discontinue proceedings unless the parties file a request to resume proceedings within one year from the date of a decision on the suspension. As a result, the maximum length of the

sądem polskim roszczeń odszkodowawczych z tytułu naruszenia reguł konkurencji, Warszawa 2016, pp. 173-174.

18 See also A. Stawicki, B. Turno, Przedawnienie roszczeń, (in:) A. Piszcz, D. Wolski (eds.), Dochodzenie przed sądem polskim roszczeń odszkodowawczych z tytułu naruszenia reguł konkurencji, Warszawa 2016, p. 157. 
Well Begun is Half Done: Amendments to the Polish Legal Framework...

suspension period for circumstances described in Article 18 para. 2 of the Directive needs to be increased. ${ }^{19}$ The drafters, rightly, do not want to do this with regard to all civil cases. Instead, they plan to draw a line between competition law cases and other cases for this purpose. In other words, Articles 178 and 182 of the Civil Procedure Code are going to remain a common denominator in all contentious civil cases, whereas the draft Act contains a specific provision (Article 14) increasing the period specified by Article $182 \$ 1$ of the Code to two years for competition law cases in which the parties had attempted consensual dispute resolution. In fact, a two-year period seems sufficiently long to arrive at an agreement in any form of consensual dispute resolution.

\subsection{Fines}

Lastly, a mitigating effect of consensual dispute resolution on a fine being imposed by a competition authority for an infringement of competition law is worthy of special mention (Article 18 para. 3 of the Directive). The authority may consider compensation - paid as a result of a consensual settlement and prior to its decision imposing a fine - to be a mitigating factor. According to Article 2(22) of the Directive, consensual settlement means an agreement reached through consensual dispute resolution.

The focus of Article 18 para. 3 of the Directive is on the effect of a type that is different from the effects provided for in paragraphs 1 and 2, since it is related to public enforcement of competition law which remains very important in numerous Member States. It is worth referring here to the aforementioned Recital 5 of the Directive. Along with consensual dispute resolution, it enumerates the concept of "public enforcement decisions that give parties an incentive to provide compensation". Decisions imposing fines referred to in Article 18 para. 3 may be considered to be such incentivising decisions. However, in scholarly commentary, the future frequency of such decisions is called into question, as antitrust damages claims are usually submitted as follow-on actions in EU Member States. ${ }^{20}$ In simple terms, it can be presumed that most consensual settlements will follow a prior infringement decision issued by a NCA. We must also be aware of the fact that using the word "may" in Article 18 para. 3, the EU legislature made room in the application of this provision for it is dependent on the discretion of competition authorities.

Although Article 18 para. 3 of the Directive may appear less complicated than some other provisions presented in this paper, it poses a serious question. Is its scope limited only to cases in which compensation was paid prior to the decision imposing a fine? Did the EU legislature exclude therefrom situations where a consensual settlement is reached following the decision imposing a fine or prior to the decision but

19 As postulated by M. Modzelewska de Raad, Polubowne..., op. cit., p. 174.

20 R. Moisejevas, The Damages Directive..., op. cit., p. 189. 
due to the parties' agreement that compensation is paid later? The positive answer would not result from Article 18 para. $3 .{ }^{21}$ However, at least in the first situation, competition authorities and review courts should take into consideration that this provision has been intended to contribute to the expedition of consensual settlement and to ease enforcement of competition law.

Currently, provisions of the Polish Act on Competition and Consumer Protection, ${ }^{22}$ amended to a considerable extent as of 18 January 2015, Article 111 in particular regarding aggravating and mitigating factors, are compliant with Article 18 para. 3 of the Directive. Rightly, the drafters have not taken any steps to further amend it.

\section{Effect of consensual settlements on subsequent actions for damages}

Last but not least, Article 19 of the Directive provides for the effect of consensual settlements on subsequent actions for damages. The rules on the above are as follows:

- following a consensual settlement, the claim of the settling injured party must be reduced by the settling co-infringer's share of the harm that the infringement of competition law inflicted upon the injured party (para. 1),

- any remaining claim of the settling injured party shall be exercised only against non-settling co-infringers; the latter shall not be permitted to recover contribution for the remaining claim from the settling co-infringer; this is the so-called "non-contribution rule" (para. 2),

- by way of derogation ${ }^{23}$ from para. 2, Member States shall ensure that where the non-settling co-infringers cannot pay the damages that correspond to the remaining claim of the settling injured party, the settling injured party may exercise the remaining claim against the settling co-infringer; this derogation may be expressly excluded under the terms of the consensual settlement (para. 3),

- when determining the amount of contribution that a co-infringer may recover from any other co-infringer in accordance with their relative responsibility for the harm caused by the infringement of competition law, national courts shall take due account of any damages paid pursuant to a prior consensual settlement involving the relevant co-infringer (para. 4, see also Recital 52 of the Directive).

The above solutions have been introduced to encourage consensual settlements. In particular, the EU legislature has been aware that an infringer who pays damages

21 See also F. Wijckmans, M. Visser, S. Jaques, E. Noël, The EU Private..., op. cit., p. 76.

22 The Act of 16 February 2007, consolidated text Journal of Laws 2015, item 184, as amended.

23 Mandatory derogation; see F. Wijckmans, M. Visser, S. Jaques, E. Noël, The EU Private..., op. cit., p. 78 . 
Well Begun is Half Done: Amendments to the Polish Legal Framework...

through consensual dispute resolution should not be placed in a worse position vis-à-vis its co-infringers than it would otherwise be without the consensual settlement (Recital 51 of the Directive).

The corollary to the non-contribution rule is that the claim of the injured party should be reduced by the settling infringer's share of the harm caused to it, regardless of whether the amount of the settlement equals or is different from the relative share of the harm that the settling co-infringer inflicted upon the settling injured party. Without such a reduction, non-settling infringers would be unduly affected by settlements to which they were not a party.

However, in order to ensure the right to full compensation (Article 3 of the Directive), settling co-infringers should still have to pay damages where that is the only possibility for the settling injured party to obtain compensation for the remaining claim. The latter possibility to claim damages from the settling co-infringer exists unless it is expressly excluded under the terms of the consensual settlement; Article 19 of the Directive expressis verbis provides for the possibility to amend a consensual settlement by expressly excluding additional liability. ${ }^{24}$

The rules contained in Article 19 paras 1-3 of the Directive do not have equivalents in provisions of the Polish Civil Code on joint and several liability (Articles 366 et seq.); thus, in the scholarly commentary amendments were recommended from the very beginning of the discussion on the transposition of the Directive. ${ }^{25}$ The drafters proposed to introduce them, as a lex specialis vis-à-vis the Civil Code, in Article 6 of the draft Act, consisting of two paragraphs. The proposed provisions are not controversial and they were not questioned during public consultations.

\section{Summary}

The Damages Directive contains important provisions regarding consensual dispute resolution in competition law cases that are absent in the Polish legal framework. They seem to have the potential to increase the application of various forms of consensual dispute resolution in this category of cases. However, such provisions may raise some more or less serious doubts. It certainly does not facilitate their transposition into the national legal framework.

The Polish legislature has not implemented the Directive in a timely manner. ${ }^{26}$ However, what the governmental drafters managed to do, can be described with the phrase used in the title of this article: "Well begun is half done". Their draft is certainly a good starting point for further legislative works. Most of their assumptions do not cause any concerns. With regard to consensual dispute resolution, however, Article

24 R. Moisejevas, The Damages Directive..., op. cit., p. 189.

25 M. Modzelewska de Raad, Polubowne..., op. cit., p. 180.

26 The paper has been finished on 30 December 2016. 
18 para. 1 of the Directive should be implemented in a different way (see above). The draft Act seems to be near passage by the Parliament so one should not expect many differences between the current draft and the Act that will eventually be passed, especially in light that the draft is already considered as quite mature. Nonetheless, the results of the amendments will not be seen for several years from now. Many practitioners and scholars will look forward to the noticeable effects of the amendments, since at the present time consensual dispute resolution does not occupy a prominent position in Poland, particularly in competition law cases.

\section{BIBLIOGRAPHY}

Modzelewska de Raad M., Polubowne rozstrzyganie sporów wynikających ze szkód wyrządzonych naruszeniem prawa konkurencji, (in:) A. Piszcz, D. Wolski (eds.), Dochodzenie przed sądem polskim roszczeń odszkodowawczych z tytułu naruszenia reguł konkurencji, Warszawa 2016.

Moisejevas R., The Damages Directive and Consensual Approach to Antitrust Enforcement, "Yearbook of Antitrust and Regulatory Studies" 2015, vol. 8(12).

Piszcz A., Piecemeal Harmonisation Through the Damages Directive? Remarks on What Received Too Little Attention in Relation to Private Enforcement of EU Competition Law, "Yearbook of Antitrust and Regulatory Studies" 2015, vol. 8(12).

Piszcz A., Polish Civil Proceedings: Expanding the Floor for Preparatory Stage, (in:) L. Ervo, A. Nylund (eds.), Current Trends in Preparatory Proceedings, Cham 2016.

Stawicki A., Turno B., Przedawnienie roszczeń, (in:) A. Piszcz, D. Wolski (eds.), Dochodzenie przed sądem polskim roszczeń odszkodowawczych z tytułu naruszenia reguł konkurencji, Warszawa 2016.

Wijckmans F., Visser M., Jaques S., Noël E., The EU Private Damages Directive - Practical Insights. Minutes of the Closed Workshop 2015, Cambridge - Antwerp - Portland 2015. 